\title{
Correlation of depression and anxiety with smartphone addiction among medical clerkship
}

\author{
I Gde Yudhi Kurniawan', \\ Luh Nyoman Alit Aryani², \\ Lely Setiawati2, \\ I Made Rustika ${ }^{3}$
}

'Department of Psychiatry, Bali Provincial Mental Hospital, Bangli, Indonesia

${ }^{2}$ Department of Psychiatry, Faculty of Medicine, Udayana University, Bali, Indonesia

${ }^{3}$ Department of Psychology, Faculty of Medicine, Udayana University, Bali, Indonesia

\begin{abstract}
Background: Smartphone is a mobile phone with operating system and internet access that has many functions and can be helpful for medical clerkship students to finish their assignments and as well as an entertainment media. Excessive and uncontrolled use of smartphone may lead to smartphone addiction. Depression and anxiety might correlate with smartphone addiction. The goal of this study was to determine the correlation of depression and anxiety with smartphone addiction among medical clerkship students in Bali province.

Materials and Methods: The research was an observational non-experimental study with cross sectional design, and descriptive analytic analysis. Samples were obtained by systematic sampling. Instruments used were the Modified Smartphone Addiction Scale Indonesian version and Depression Anxiety Stress Scale 42 (DASS 42). Data were analyzed by Spearman's test then simple regression analysis for anxiety and smartphone addiction because depression did not fulfill assumption test.

Results: A number of 100 samples were analyzed. Depression was positively correlated to smartphone addiction $(\mathrm{r}=0.542, \mathrm{p}<0.001)$. Anxiety was positively correlated to smartphone addiction $(r=0.598, p<0.001)$. Simple regression analysis showed a value of $R=0.591(p<0.001)$ and as such anxiety played role on smartphone addiction. A determination coefficient of 0.349 showed the effective role of anxiety on smartphone addiction was $34.9 \%$ whereas the remaining $75.1 \%$ was determined by another variable that were not investigated on this study.

Conclusion: There was a significant positive relationship with the strength of a moderate relationship between depression and anxiety with smartphone addiction.
\end{abstract}

Keywords: smartphone addiction, depression, anxiety, medical clerkship students

\section{Introduction}

The use of smartphones becomes very vital for students because it is not only the same as what is provided by the internet but also explores various applications that provide many new functions. Smartphones are used as a tool to support learning activities such as reading e-books, studying lecture material and presentation slides, listening to lecturer recordings while teaching to watching video tutorials. ${ }^{1}$ Studies at three universities in Korea on business administration, economics and computer science study programs show that smartphones are more widely used by students with a percentage of $66.9 \%$ and $33.1 \%$ used by practitioners. ${ }^{2}$

Depression is a psychological factor that is suspected to increase the risk of smartphone addiction. ${ }^{3}$ Individuals with depression tend to withdraw from social situations, are lazy to move and eventually become lonely. Kim et al. ${ }^{4}$ revealed that individuals with depression used their smartphones as coping mechanisms to make peace with their depression.

Another psychological factor that is thought to cause smartphone addiction is anxiety. Anxiety is characterized by worry, fear and palpitations. In addition, individuals with anxiety tend to avoid face-to-face communication. Anxiety, anxious personality traits, and depression were found to be higher in the smartphone user group than in the normal user group. ${ }^{5}$ Based on the above, researchers are interested in examining the relationship between depression and anxiety with smartphone addiction in the medical students.
Corresponding author: Department of Psychiatry, Faculty of Medicine, Udayana University

Jl. Kesehatan I, Denpasar 80II4

Bali, Indonesia

Email: alit_aryani@unud.ac.id 


\section{Material and Methods}

This study is a correlational analytic study with a crosssectional study approach to determine the effect of depression and anxiety with smartphone addiction. This research was conducted at the Faculty of Medicine of Udayana University and Warmadewa University.

Data sources were collected directly from research subjects (as primary data). Data collection is done by using an online questionnaire in Google form. The inclusion criteria included medical students aged 21-25 years who were willing to participate in the study by signing an informed consent. Exclusion criteria included previous history of severe mental disorder, anxiety, or depression. All respondents who did not fill the questionnaire completely were also removed from the subjects.

Smartphone addiction on research subjects was measured by modification of the Indonesian version of Smartphone Addiction Scale. Depression in the study subjects was measured by a DASS-D score where the higher the DASS-D value the higher the occurrence of depression. Anxiety in the study subjects was measured by a DASS-A score where the higher the DASS-A score, the higher the anxiety.

The questionnaire is distributed to respondents through short messages services (SMS) by including the questionnaire link on the Google form. The research data is tabulated from Google form in the form of Microsoft Excel files, then processed with the help of a computer using Statistical Package for the Social Sciences (SPSS) for windows and displayed in tables, graphics and narratives. First the assumption test is carried out, then the next hypothesis test.

\section{Results}

The research enrolled 253 subjects from two universities (Table 1). The sampling interval for systematic sampling is set every three times, until 100 people is chosen. The average age of the subjects was 23 years consisting of $54 \%$ women and $46 \%$ men.

Table 1. Subject Characteristics

\begin{tabular}{lcc}
\hline Characteristic & Mean \pm SD & N $(\%)$ \\
\hline Age (years), mean \pm SD & $23.08 \pm 0.56$ & \\
\hline Sex, n(\%) & \\
Man & & \\
Woman & $54(46 \%)$ \\
\hline Religion, n(\%) & \\
Hindu & $80(80 \%)$ \\
Islam & $6(6 \%)$ \\
Protestant & $6(6 \%)$ \\
Catholic & $7(7 \%)$ \\
Buddha & $1(1 \%)$ \\
\hline Ethnic, n(\%) & \\
Bali & $81(81 \%)$ \\
Jawa & $7(7 \%)$ \\
Batak & $2(2 \%)$ \\
Tionghoa & $9(9 \%)$ \\
Others & $1(1 \%)$ \\
\hline
\end{tabular}

Table 2. Observed findings

\begin{tabular}{lcc}
\hline Characteristic & Mean \pm SD & $\mathrm{N}(\%)$ \\
\hline Total smartphone held & & \\
One & & $83(83 \%)$ \\
Two & $17(17 \%)$ \\
Age when first time had a & $15.18 \pm 2.66$ & \\
smartphone (years) & & \\
$<10$ & & $4(4 \%)$ \\
$11-14$ & $33(33 \%)$ \\
$15-18$ & $53(53 \%)$ \\
$>18$ & $10(10 \%)$ \\
The main use of smartphones & \\
Telephone & $6(6 \%)$ \\
Internet browsing & $20(20 \%)$ \\
Social networking & $69(69 \%)$ \\
Medical application & $3(3 \%)$ \\
Games & $2(2 \%)$ \\
Duration of smartphone usage per & $7.61 \pm 4.11$ & \\
day (hours) & \\
$<2$ & & $6(6 \%)$ \\
$2-4$ & & $21(21 \%)$ \\
$5-7$ & $24(24 \%)$ \\
$8-10$ & $31(31 \%)$ \\
$>10$ & $18(18 \%)$ \\
Time lag between waking up and & $27.42 \pm 9.05$ & \\
using a smartphone & \\
$<5$ minutes & \\
$5-30$ minutes & & \\
$>30$ minutes & & $32(42 \%)$ \\
& & $21(21 \%)$ \\
\hline
\end{tabular}

Table 3. Categories of Smartphone Addiction

\begin{tabular}{llcc}
\hline Range Value & Category & Total & $\%$ \\
\hline $\mathrm{X} \leq 47.25$ & Very Low & 1 & 1 \\
$47.25<\mathrm{X} \leq 64.75$ & Low & 45 & 45 \\
$64.75<\mathrm{X} \leq 82.25$ & Medium & 48 & 48 \\
$82.25<\mathrm{X} \leq 99.75$ & High & 6 & 6 \\
$99.75<\mathrm{X}$ & Very High & 0 & 0 \\
\hline
\end{tabular}

Table 4. Depression Categories

\begin{tabular}{llrc}
\hline Range Value & Category & Total & $\%$ \\
\hline $0-9$ & Normal & 98 & 98 \\
$10-13$ & Mild & 0 & 0 \\
$14-20$ & Moderate & 2 & 2 \\
$21-27$ & Severe & 0 & 0 \\
$>28$ & Very Severe & 0 & 0 \\
\hline
\end{tabular}

Table 2 shows that the majority of medical students carried one smartphone (83\%). The most common uses of smartphones were for social networking (69\%), internet browsing (20\%), telephones (6\%), medical applications (3\%), and games (2\%). The average length of smartphone usage in a day is 7.61 hours. When classified as most between 8-10 hours (31\%) then 5-7 hours (24\%), 2-4 hours (21\%) and more than 10 hours (18\%).

Table 3 shows the prevalence of smartphone addiction of the subjects. While Table 4 shows the prevalence of depression of the subjects. As many as $6 \%$ experienced a high level of smartphone addiction, $48 \%$ experienced a moderate level of smartphone addiction and the rest were low and very low.

Table 5 shows subjects experiencing moderate anxiety was $13 \%$, mild anxiety $11 \%$ and the rest in the normal category. After the assumption test requirements are fulfilled (data is normally distributed and is linear) a simple regression analysis is performed. The results of the regression analysis are summarized in Table 6. 
Table 5. Anxiety Categories

\begin{tabular}{llcc}
\hline Range Value & Category & Total & $\%$ \\
\hline $0-7$ & Normal & 76 & 76 \\
$8-9$ & Mild & 11 & 11 \\
$10-14$ & Moderate & 13 & 13 \\
$15-19$ & Severe & 0 & 0 \\
$>20$ & Very Severe & 0 & 0 \\
\hline
\end{tabular}

Table 6. Regression Test

\begin{tabular}{cccc}
\hline $\mathrm{R}$ & R-square & Adjusted R Square & Std. Error of the Estimate \\
\hline 0.591 & 0.349 & 0.342 & 7.595 \\
\hline
\end{tabular}

Regression analysis results showed a regression coefficient (R) of 0.591 and a coefficient of determination ( $R$ Square) of 0.349 . Thus, it can be mentioned anxiety determines $34.9 \%$ smartphone addiction, while the remaining $75.1 \%$ is determined by other variables not examined in this study. The independent sample $t$ test is shown in Table 7. The t-test on the same variant assumption shows a p value of $0.161(\mathrm{p}>0.05)$ so that it can be concluded statistically there is no difference in the average score of smartphone addiction in men and women.

\section{Discussion}

Addiction is a phenomenon characterized by tolerance, withdrawal symptoms and dependency accompanied by social problems. This term is not limited to substances or drugs but is currently also applied to gambling, internet, gaming, cellphone use, and other behavioral addictions. ${ }^{6}$ Smartphones can induce the emergence of addiction characteristics in their users because they have mobility and internet access capabilities. ${ }^{7}$ A study of 319 Süleyman Demirel University (Turkey) students using the Smartphone Addiction Scale found a high smartphone user group at $39.8 \% .5$ The prevalence of smartphone adicction in Indian adolescents is reported to be between $39 \%$ to $44 \%$ while overall Asian adolescents from China, Hong Kong, Japan, South Korea, Malaysia and the Philippines are reported $62 \%{ }^{8}$

There are various factors that can encourage individuals to experience smartphone addiction, one of which is a psychological factor. Studies related to smartphone addiction have greatly increased in the past decade with the majority focused on the potential that affects smartphone addiction and the relationship between smartphone addiction with relevant psychological predictive factors, the influence of social factors, cell phone use behavior, and family environmental factors. ${ }^{9}$ Many psychological factors have been studied and are associated with smartphone addiction such as loneliness, shame, self-confidence and impulsivity. ${ }^{10,11}$

The positive relationship between depression and anxiety with smartphone addiction is supported by several previous studies. Kim et al. ${ }^{4}$ conducted a study of students in South Korea with an average age of 20.27 years getting a positive correlation between depression and smartphone addiction, with a correlation coefficient of 0.383 . Demirci et al. ${ }^{5}$ conducted a study of 319 university students in Turkey with an average age of 20.5 years getting the weight of smartphone use positively correlated with depression (correlation coefficient $0.267, \mathrm{p}$ $<0.001$ ) and anxiety (correlation coefficient 0.276 , p <0.001).

Hope and Henderson ${ }^{12}$ conducted a systematic review to determine the prevalence of depression, anxiety and psychological stressors in medical students in the UK, Europe and other countries that use English. The results of 14 studies on depression found depression prevalence range between $6.0 \%$ to $66.5 \%$. The prevalence of anxiety in 11 studies found showed a range of $7.7 \%-65.5 \%$. This study found $2 \%$ with moderate depression, $13 \%$ with moderate anxiety and $11 \%$ with mild anxiety. These results are in accordance with research conducted by Shamsuddin et al. ${ }^{13}$ of 506 students in Malaysia aged 18 to 24 years and Yusoff et al. ${ }^{14}$ of 743 medical students in Malaysia where the prevalence of anxiety was higher than depression and stress.

In this study, we categorized smartphone addiction based on standard intersections. The result was $6 \%$ experienced a high level of smartphone addiction and $48 \%$ experienced a moderate level of smartphone addiction. Social networking services were the main drive for smartphone usage by $69 \%$, followed by internet browsing, telephones, medical applications, and games. These results are in accordance with Haug et al. ${ }^{15}$ who conducted a study on Swiss teenagers where smartphones were most used for social networking as much as $67.3 \%$ then listened to music $(17.8 \%)$ and made phone calls $(6.4 \%)$.

In this study, there were no significant differences in the average score of smartphone addiction between men and women ( $\mathrm{p}=0.161)$. Studies of medical students in Iran show that internet and mobile addictions are related to male sex. ${ }^{16}$

Table 7. Independent sample t-test

\begin{tabular}{|c|c|c|c|c|c|c|c|c|}
\hline & & \multicolumn{7}{|c|}{ t-test for Equality of Means } \\
\hline & & \multirow[t]{2}{*}{$\mathrm{t}$} & \multirow[t]{2}{*}{$\mathrm{df}$} & \multirow[t]{2}{*}{$\begin{array}{c}\text { Sig. } \\
\text { (2-tailed) }\end{array}$} & \multirow[t]{2}{*}{$\begin{array}{c}\text { Mean } \\
\text { Difference }\end{array}$} & \multirow[t]{2}{*}{$\begin{array}{l}\text { Std. Error } \\
\text { Difference }\end{array}$} & \multicolumn{2}{|c|}{$\begin{array}{l}95 \% \text { Confidence } \\
\text { Interval of the } \\
\text { Difference }\end{array}$} \\
\hline & & & & & & & Lower & Upper \\
\hline \multirow[b]{2}{*}{$\begin{array}{c}\text { Smartphone } \\
\text { Addiction }\end{array}$} & $\begin{array}{l}\text { Equal } \\
\text { variances } \\
\text { assumed } \\
\end{array}$ & -1.412 & 98 & 0.161 & -2.639 & 1.870 & -6.350 & 1.071 \\
\hline & $\begin{array}{l}\text { Equal } \\
\text { variances } \\
\text { not } \\
\text { assumed } \\
\end{array}$ & -1.398 & 90.941 & 0.165 & -2.639 & 1.888 & -6.389 & 1.110 \\
\hline
\end{tabular}


Kim et al. ${ }^{4}$ in South Korean students found smartphone addiction to be more severe in men than women. But studies in South Korean and Turkish students show higher levels of smartphone addiction in women, compared to men. . $^{5,17}$

The weakness of this study is that one of the three variables studied is depressive variables that are not normally distributed so that double regression analysis cannot be performed and it cannot be known the effective contribution of depression variables compared to anxiety variables. Correlation analysis uses non-parametric analysis so the results of the study only apply to the samples in this study.

\section{Conclusion}

There was a significant positive relationship with the strength of a moderate relationship between depression and anxiety with smartphone addiction. This means that the higher the level of depression and anxiety, the higher the level of smartphone addiction and vice versa.

\section{Acknowledgment}

The authors report no conflict of interests.

\section{References}

1. Al-Barashdi H, Bouazza A, Jabur N. Smartphone Addiction among University Undergraduates: A Literature Review. Journal of Scientific Research and Reports. 2015;4(3):210225.

2. Jung W, Yim H. The Effects of Cognitive Functions of Smartphone Users on their Behavioral Intention. Advanced Science and Technology Letters. 2014;63:183-186. doi: 10.14257/astl.2014.63.40.

3. Elhai JD, Dvorak RD, Levine JC, Hall BJ. Problematic smartphone use: A conceptual overview and systematic review of relations with anxiety and depression psychopathology. $\mathbf{J}$ Affect Disord. 2017;207:251-259. doi: 10.1016/j.jad.2016.08.030.

4. Kim M, Kim H, Kim K, Ju S, Choi J, Yu M. Smartphone Addiction: Focused Depression, Aggression and Impulsion among College Students. Indian Journal of Science and Technology. 2015;8(25):326-332.

5. Demirci K, Akgönül M, Akpinar A. Relationship of smartphone use severity with sleep quality, depression, and anxiety in university students. Journal of Behavioral Addictions. 2015;4(2):85-92.
6. Kwon M, Lee JY, Won WY, et al. Development and validation of a smartphone addiction scale (SAS). PLoS One. 2013;8(2):e56936. doi:10.1371/journal.pone.0056936

7. Ezoe S, Iida T, Inoue K, Toda M. Development of Japanese version of Smartphone Dependence Scale. Open Journal of Preventive Medicine. 2016;7:179-185.

8. Kahyaoglu H, Kurt S, Uzal O, Ozdilek S. Effects Of Smartphone Addiction Level On Social And Educational Life In Health Sciences Students. Euras J Fam Med. 2016;5(1):13-19.

9. Chiu SI. The relationship between life stress and smartphone addiction on taiwanese university student: A mediation model of learning self-Efficacy and social self-Efficacy. Computers in Human Behavior. 2014;34:49-57. doi: 10.1016/j.chb.2014.01.024.

10. Wu AMS, Cheung VI, Ku L, Hung EPW. Psychological risk factors of addiction to social networking sites among Chinese smartphone users. Journal of Behavioral Addictions. 2013;2(3):160-6. doi: 10.1556/JBA.2.2013.006.

11. Bian M. Leung L. Linking loneliness, shyness, smartphone addiction symptoms, and patterns of smartphone use to social capital. Social Science Computer Review. 2015;33(1):61-79.

12. Hope V, Henderson M. Medical student depression, anxiety and distress outside North America: a systematic review. Medical education. 2014;48(10):963-979.

13. Shamsuddin K, Fadzil F, Ismail WS, Shah SA, Omar K, Muhammad NA, Jaffar A, Ismail A, Mahadevan R. Correlates of depression, anxiety and stress among Malaysian university students. Asian J Psychiatr. 2013;6(4):318-23. doi: 10.1016/j.ajp.2013.01.014.

14. Yusoff MS, Abdul Rahim AF, Baba AA, Ismail SB, Mat Pa MN, Esa AR. Prevalence and associated factors of stress, anxiety and depression among prospective medical students. Asian J Psychiatr. 2013;6(2):128-33. doi: 10.1016/j.ajp.2012.09.012.

15. Haug S, Castro RP, Kwon M, Filler A, Kowatsch T, Schaub MP. Smartphone use and smartphone addiction among young people in Switzerland. Journal of Behavioral Addictions. 2015;4(4):299-307.

16. Mazaheri MA, Najarkolaei FR. Cell Phone and Internet Addiction among Students in Isfahan University of Medical Sciences (Iran). Journal of Health Policy and Sustainable Health. 2014;1(3):69-73.

17. Choi SW, Kim DJ, Choi JS, Ahn H, Choi EJ, Song WY, Kim $\mathrm{S}$, Youn H. Comparison of risk and protective factors associated with smartphone addiction and Internet addiction. J Behav Addict. 2015;4(4):308-14. doi: 10.1556/2006.4.2015.043. 